UDK: $80(=163.4 * 3): 811.21 / .41(497.6)^{\text {“c15/18“ }}$

Mersiha Čaušević, asistent

Izvorni naučni rad

Univerzitet u Bihaću

Islamski pedagoški fakultet

mersihacausevic78@yahoo.com

\title{
FILOLOGIJA BOŠNJAKA NA ORIJENTALNIM JEZICIMA ZA VRIJEME OSMANSKE VLADAVINE U BOSNI
}

\section{Sažetak}

Ovaj rad sadrži popis filoloških djela koja su napisali Bošnjaci u periodu između 16. $i$ 19. st., za vrijeme vladavine Osmanlija ovim prostorima. Rukopisi ovih djela na arapskom, turskom i perzijskom jeziku nalaze se po bibliotekama sirom svijeta, a djela koja su nama do sada poznata nabrojana su u radu, stim da uvijek postoji mogućnost da se neki novi rukopis pronade (ili postojeći prevede). Najviše naše filološke baštine pripada arapskom jeziku. Iz rukopisa koji su prevedeni na savremeni bosanski jezik, predstavljeni su odredeni dijelovi iz kojih se može vidjeti način na koji se tad pisalo, koje su to klasične knjige bile najpopularnije, te kao takve služile kao udžbenici. Jedna od tih knjiga je Ibn Häğibova arapska sintaksa al-Käfiyya, često komentirana $i$ prilagodavana potrebama tadašnjeg obrazovnog sistema. Između ostalih, navode se i filološka djela Hasana Kafije Pruščaka, koji kod nas nije poznat kao filolog, da se istinski zanimao za filologiju potvrduje podatak da je on svoj komentar Talhisa korigirao pisanjem novog komentara, isto u edukacijske surhe. Takoder, iako napisane na evropskim jezicima, gramatike turskog jezika dobile su svoje mjesto u radu zato što razlozi zbog kojih su bosanski franjevci pisali gramatike i rječnike nisu isti kao razlozi učenja turskog jezika muslimanskog stanovništva. I na kraju, predstavljen je dio filoloških rasprava o perzijskom jeziku Ahmeda Sudija Bošnjaka.

Ključne riječi: Filologija, arapski jezik, turski jezik, perzijski jezik, rukopis, gramatika, sintaksa, stilistika, komentar, Bošnjak, Mustafa Ejubović Šejh Jujo, Hasan Kafija Pruščak, Ahmed Sin Hasanov, Ahmed Sudi, franjevci, 


\section{Uvod}

Za vrijeme Osmanskog carstva, Bošnjaci su mnogo doprinijeli svojom djelatnošću u raznim znanstvenim oblastima, uključujući filologiju. U okviru Osmanskog carstva tri jezika su bila dominantna: arapski - jezik znanosti, prava i teologije, turski - jezik administracije i profane književnosti, i perzijski - jezik poezije. ${ }^{1}$ Ubrzo nakon osmanskog osvojenja Bosne (1463. godine), Bošnjaci počinju davati doprinos stvaralaštvu uopće, i to upravo na ova tri jezika. Jedan od karakterističnih načina pisanja tog doba, pa tako i pisanja Bošnjaka tog perioda jesu komentari i glose (znanstveni tekstovi pisani su najčešće na arapskom) na već napisana djela. Iako danas ovakav način stvaranja djela izgleda kao imitiranje već napisanog djela, tada je to bio uobičajen način rada. Međutim, i ti komentari su sadržavali određenu dozu originalnosti i samostalno-istraživačkog rada komentatora, i to u skladu sa njegovim poznavanjem oblasti o kojoj piše. Svrha komentara je najčešće bila udžbeničke prirode, odnosno služila za školske potrebe, s ciljem pojašnjenja određenih dijelova i lakšeg razumijevanja osnovnog teksta. Općenito uzevši, najviše djela napisano je na turskom jeziku (administrativna prepiska sa Portom), zatim na arapskom, pa perzijskom. ${ }^{2}$ Iz oblasti filologije najviše djela napisano je na arapskom jeziku. Veliki broj Bošnjaka koji su živjeli u ovom periodu pisao je, pored bosanskog, na sva tri ova jezika.

\section{Djela Bošnjaka na arapskom jeziku iz oblasti filologije}

\subsection{Gramatika i sintaksa}

Nekoliko Bošnjaka koji su se bavili arapskom filologijom javilo se već u XVI stoljeću. Među njima su: Ahmed Sudić, ${ }^{3}$ Muhammed Musić

\footnotetext{
1 Vidjeti kod: Hazim Šabanović, Književnost muslimana BiH na orijentalnim jezicima, Sarajevo, Svjetlost, 1973. str.14. Isto i u:, „, Književnost muslimana BiH na orijentalnim jezicima“, Bošnjačka književnost u književnoj kritici, knjiga I str. 212 220, Sarajevo, 1998.

2 Vidjeti više u: Sulejman Grozdanić, „Pisana riječ na orijentalnim jezicima i alhamijado“, Bošnjačka književnost u književnoj kritici, str.253-270

${ }^{3}$ Mustafa Jahić, Arapska gramatika u djelu al-Fawā'id al- 'abdiyya, str.719, isto u: Hazim Šabanović, Književnost Muslimana BiH na orijentalnim jezicima, str.94
} 
Allamek, ${ }^{4}$ Ismail Travničanin ${ }^{5}$, Mustafa Ejubović Šejh Jujo, te njegov učenik Ibrahim Opijač. ${ }^{6}$ Zatim, tu su još i Mustafa Orudž i Opijačev sin Abdullah $^{7}$ i mnogi drugi.

Međutim, izučavanje gramatike arapskog jezika u Bosni zasigurno ima dugu tradiciju, jer se bilježi da je već 1573. neki Bosanac Sinan, sin Ejnbega, prepisao Ibn Hāğibovu sintaksu al- Käfiya. ${ }^{8}$

Neki od tih rukopisa su prevedeni i interpretirani posljednjih godina na bosanski jezik. Među našim savremenim istraživačima ovog perioda su Amra Mulović i Mustafa Jahić koji su se bavili komentarima Mustafe Ejubovića Šejha Juje iz oblasti gramatike arapskoga jezika, pa ćemo malo pogledati ta njihova istraživanja Šejh Jujinih komentara. Prvi od njih je:

\subsection{1.a Mustafa Ejubović Šejh Jujo - Šarḥ al-‘Awāmil al-m'ia}

Šarh al-'Awāmil al-m'ia (Komentar „Stotinu regensa u sintaksi“), napisan na Ğurğānijevo djelo 'Awāmil al-m'ia al-nahwiyya, a koje se ponekad naslovljava sa Kitāb al- 'awāmil. ${ }^{9} \mathrm{Na}$ bosanski jezik prevela ga je i obradila Amra Mulović.

Ovaj Šejh Jujin Komentar objašnjava regense, tj. pojmove koji su upravni elementi unutar određene sintagme ili rečenice, te uzrokuju određene oblike zavisnih elemenata. Ğurğāni je naveo stotinu regensa, koje je podijelio na dvije skupine: formalne $i$ semantičke. Formalni regensi se dijele na dvije skupine: jezičkom upotrebom uzakonjeni $i$ analogijom uzakonjeni. Regensa uzakonjenih upotrebom je devedeset $i$ jedan regens, a analogijom uzakonjenih je sedam i semantičkih je dva. ${ }^{10}$

4 M. Jahić, Arapska gramatika..., str.720; isto u Hazim Šabanović, Književnost Muslimana BiH..., str. 146-147

${ }^{5}$ M. Jahić, Arapska gramatika..., str.720; isto u Hazim Šabanović, Književnost Muslimana BiH..., str. 244-246

${ }^{6}$ M. Jahić, Arapska gramatika..., str.720; isto u Hazim Šabanović, Književnost Muslimana BiH..., str. 439-445

${ }^{7}$ Amra Mulović, Arapska gramatička tradicija u Bosni: Šejh Jujo o regensu, str.11

${ }^{8}$ Ibid., str. 11

${ }^{9}$ Ibid., str. 5

${ }^{10}$ Ibid., str.29-32 (citiran samo Gurğānijev tekst, koji je boldiran) 
Ta podjela je osmišljena tako da regensi po upotrebi razdjeljuju se na trinaest kategorija. ${ }^{11}$

Prva kategorija: prijedlozi koji zahtijevaju genitiv jednog imena, i to njih 17: bi, min, 'ilā, fì, li, rubba, 'alā, 'an, ka, mud $/ m u n \underline{d} u$, hattā, zatim $w a, b i$ i ta za zakletvu, te hăšs̆a, 'adā i halā za izuzimanje. Druga kategorija: partikule koje zahtijevaju akuzativ subjekta i nominativ predikata, a to su: 'inna, 'anna, ka'anna, lākinna, layta i la 'alla. Treća kategorija su dvije partikule koje zahtijevaju nominativ subjekta i akuzativ predikata imenske rečenice. To su $m \bar{a}$ i $l \bar{a}$ koje sliče laysa, ${ }^{12}$ itd.

Tako se u ovom al-Ğurğānijevom djelu i njegovom komentaru Mustafe Ejubovića Šejha Juje do broja stotinu.

Prema sadržaju i osnovnog (izvornog) djela i komentara, vidimo da se najviše pažnje dalo prijedlozima u arapskom jeziku, s tim da je Šejh Jujo ponekad govorio i o prilozima, na način da ih objašnjava, i etimološki i semantički, ${ }^{13}$ dok na nekim mjestima podrobno objašnjava sva moguća značenja određene riječi, ${ }^{14}$ gdje se jasno vidi i njegovo poznavanje nijansi značenja, pa kad govori o tome da se prijedlog 'alā javlja u značenju prijedloga min, pozivajući se na Šarḥ al-mašāriq, pa npr. kaže da ako neko pita kakva je razlika između min $i$ 'an reći ćemo da ako kažeš harağtu 'an al-baladi Izašao sam iz zemlje znači da ne želiš povratak, a ako kažeš harağtu min al-baladi onda želiš da se vratiš ${ }^{15}$

Mustafa Ejubović Šejh Jujo je uglavnom nastojao objasniti kroz primjere ono o čemu Ğurğāni govori, npr. za glagol 'as $\bar{a}$, za koji Ğurğāni daje primjer 'as̄̄ Zayd 'an yahruğa (Zejd će možda izaći), šejh Jujo objašnjava da je riječ Zayd u nominativu, budući da je subjekat, a

\footnotetext{
${ }^{11}$ Ibid., str.33

${ }^{12}$ Ibid., str. 77

${ }^{13}$ Ibid.,str. 42

${ }^{14}$ Ibid., str.54
}

${ }^{15}$ Vidjeti u : Ibid., str.54-55. Ovdje se kao sedmi prijedlog obrađuje 'alā, za koji piše da se koristi u značenju min, a u navedenim primjerima Šejh Jujo je, umjesto primjera za semantičko podudaranje prijedloga 'alā i min dao primjerkoristeći prijedlog 'an, koji se nalazi, kao i primjeri njegove upotrebe tek iza u tekstu, kao osmi prijedlog. Ovo se može pročitati i u rukopisu Komentara, koji je Amra Mulović dodala na kraju svoga rada, na str. 179 
'an yahuğa je na poziciji predikata u akuzativu ${ }^{16}$, itd., pa kaže: Gramatičari su raspravljali o 'asā te ko želi o ovome saznati detalje, neka pogleda u al-Fawā'id al-diyā'iyya ${ }^{17}$, odnosno ukazuje i na neka druga djela iz ove oblasti, koja su također bila predmet njegovog istraživanja.

\subsection{1.b Mustafa Ejubović Šejh Jujo - al-Fawā’id al-‘abdiyya}

Drugo djelo iz oblasti arapske gramatike koje je napisao Šejh Jujo, također u obliku komentara, je al-Fawā'id al-'abdiyya „Savjeti Abdullahu“. Ovo djelo je komentar na al-Zamahšarijevo djelo alUnmū $\underline{d} a \breve{g} f i$ al-naḥw. Na bosanski jezik ga je preveo i obradio Mustafa Jahić.

Za razliku od prethodno navedenog djela, koje se bavi isključivo prijedlozima, ova gramatika započinje definiranjem riječi, potom slijede imena, glagoli, te partikule.

Šejh Jujo se zaista posvetio detaljnoj razradi svake ove oblasti. To možemo vidjeti iz sljedećeg primjera; kada govori o uzrocima nepotpune promjenljivosti imenica, gdje kaže: Ovih uzroka, prema osnovnom djelu, ima devet i svaki od njih posebno se tretira u tekstu koji slijedi... Prije nego što će prijeći na tumačenje uzroka nepotpune sufiksalne promjenljivosti imenica, Ejubović ističe da autor djela alLubāb navodi $i$ deseti razlog..., ${ }^{18}$ iz čega možemo zaključiti da je obratio pažnju i na mišljenja drugih autora.

Potom, Šejh Jujo objašnjava kroz primjere sve nabrojane uzroke nepotpune promjenljvosti imenica i zaključuje: jedan razlog je nedovoljan da bi mogao utjecati na nepromjenljivost imenica, osim ako se ponovi. Imenica s jednim razlogom, kako dalje ističe Ejubović, varira između svoje izvorne i sekundarne prirode, ali na kraju promjenjivost kao izvorna osobina imenice prevladava i imenica postaje potpuno

\footnotetext{
${ }^{16}$ Ibid., 114

${ }^{17}$ Ibid., 115

18 Mustafa Jahić, Arapska gramatika u djelu al-Fawā'id al-'abdiyya, Sarajevo, 2007.,str.88
} 
promjenjiva. Kada se, međutim, nađu dva razloga, onda prevladava sekundarna osobenost imenice $i$ ona postaje nepotpuno promjenljiva. ${ }^{19}$ Međutim, pored tumačenja al-Zamahšarījevog teksta, Šejh Jujo navodi i mišljenje al-Isfarā 'innija koji ističe da se u imenicama Nūh i Lüt nalaze dva razloga nepotpune promjenljivosti, da su strane riječi i kao vlastite imenice determinirane, tako da bi na osnovu analogije trebale biti nepotpuno promjenljive, ali su postale promjenljive zato što je lahkoća izgovora (hiffa) nadjačala jedan od dva navedena razloga nepotpune promjenljivosti. ${ }^{20}$

Ovdje se vidi da se Mustafa Ejubović ne slaže sa stavom alZamaȟšāīija, jer navodi i mišljenje al-Isfarā’̄innija, te još dodaje, kao potvrdu vlastitog stava $i$ kur'anski ajetetista smo Mi Nuha narodu njegovu poslali $u$ kojem se imenica Nūh navodi kao potpuno promjenljiva. ${ }^{21}$

Proučavajući ovaj Ejubovićev komentar, Jahić je, između ostalog primijetio da on isto tako ponekad pokazuje $i$ nezavisnost prema osnovnim izvorima svoga rada, prije svega prema al-Zamahšariju $i$ njegovom al-Mufașșalu ${ }^{22}$, kao, npr., kod definiranja rečenice kad ne prihvata njegov stav da su kalām $i$ ğumla sinonimi, ističući da je prema njemu ğumla šireg značenja jer uključuje i zavisne rečenice koje ne iskazuju potpun smisao. ${ }^{23}$

Ejubović u svome komentaru često polemizira i sa drugim autorima, kao kad odbacuje al -Isfarā'inijevu tvrdnju da se imenica determinira samom subjekatskom pozicijom u rečenici. Kao protudokaz Ejubović

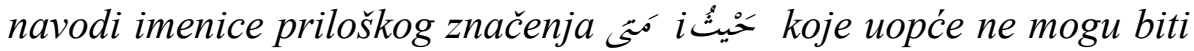
subjekat u rečenici... Ejubović često iznosi neslaganja i među drugim

\footnotetext{
${ }^{19}$ Ibid., str.92

${ }^{20}$ Ibid., str.93

${ }^{21}$ Ibid., str.93, isto na str.707

22 Izvori za al-Fawā'id al-'abdiyya bili su al-Zamahšarījev al-Mufașsal i alIsfarā'īnijev al-Lubāb. Vidjeti kod: M. Jahić, Arapska gramatika u djelu al-fawā'id al- 'abdiyya Mustafe Ejubovića, str. 18, isto str. 29, te str.708

${ }^{23}$ Ibid., str.706
} 
gramatičarima u pogledu nekih gramatičkih pitanja, kao npr., u vezi sa upotrebom imenice s veznikom poslije subjekta čestice 'inna. ${ }^{24}$

Oboje naših istraživača ova dva Šejh Jujinih komentara, i Amra Mulović, i Mustafa Jahić, čija su djela korištena u ovom radu, primijetili su da je Šejh Jujo prvenstveno bio sklon logičkom posmatranju svijeta, tako da Mulović pojašnjava aspekt njegovog djela na sljedeći način: Šejh Jujo nije izbjegao porivu svog bića logičara $i$ pera naklonjenog filozofiji jezika, ${ }^{25}$ dok Jahić kaže: Sklonost ka logičkom promatranju jezika i njegovih zakonitosti Ejubović pokazuje već na početku svoga komentara prilikom interpretiranja pojma kalima (riječi) kao temeljne jezičke jedinice i osnovnog predmeta gramatičke analize definirajući je na način kako se definira u logici. ${ }^{26}$

Koliko daleko doseže ovo njegovo logičko zaključivanje, svjedoči i sljedeće: kada govori o brojevima koji su u genitivnoj vezi sa imenicama ženskog roda nemaju nastavak $t$ čime bi se razlikovale od imenica muškog roda, on kaže da je $i$ samo izostavljenje znaka... na određeni način... znak. $^{27}$

Za djelo Šarh al- 'Awāmil al-mi'a se pretpostavlja da ga je napisao prije odlaska na studij u Istanbul, odnosno prije 1677. godine ${ }^{28}$, dok je djelo al-Fawā'id al- 'abdiyya napisano kasnije, u vrijeme nastavničkog rada u Istanbulu, a nakon završenih studija, uviđajući slabosti tadašnjeg sistema obrazovanja u osmanskom školstvu, Mustafa Ejubović pristupa pisanju radova udžbeničkog karaktera iz nekih nastavnih predmeta $i$ istovremeno novim pristupom u metodici predavanja, teorijski $i$ praktično pokušava pronaći drugačiji pristup rješavanju problema $u$ tadašnjem sistemu obrazovanja u Osmanskom carstvu. ${ }^{29}$

\footnotetext{
${ }^{24}$ Ibid., str. 707

${ }^{25}$ Amra Mulović, Arapska gramatička tradicija..., str.133

${ }^{26}$ Mustafa Jahić, Arapska gramatika $u$ djelu..., str.703

${ }^{27}$ Ibid., str. 420

${ }^{28}$ Vidjeti u : A. Mulović, Arapska gramatička tradicija..., str.14

${ }^{29}$ Mustafa Jahić, Arapska gramatika u djelu..., str.14
} 
Prema M. Ždraloviću, ovom naslovu al-Fawā'idal-'abdiyya, sam autor dao je još jedan naslov Šarḥ'alāUnmūdağal-Zamahšarī, te da je djelo završio 1683. ${ }^{30}$

Amra Mulović za Šarḥ al- 'Awāmil al-mi'a kaže: Šejh Jujini komentari razlikuju se po obimu i dubini (neki su više nego dovoljni, dok su drugi nedostatni, kad se uzme u obzir značaj određene kategorije), aspektu ( Šejh Jujo nije izbjegao porivu svog bića logičara i pera naklonjenog filozofiji jezika), ali što se tiče postupka, on je primarno, zapravo isključivo intertekstualnost, i to eksplicitna. On svo vrijeme parafrazira i citira različite stavove niza gramatičara različitih filoloških škola, a najčešće se poziva na Ibn Hāğibovu sintaksu al-Kāfiya. Pri tome rijetko iznosi svoje mišljenje... ${ }^{31}$

Ako prije studija u Istanbulu nije dovoljno iznosiosvojemišljenje, kasnije se pokazao kao izuzetan poznavalac mnogih znanosti, između ostalog i lingvistike, tako da Mustafa Jahić, na osnovu Šejh Jujinih tumačenja gramatičkih pravila u djelu al-Fawā'id al-'abdiyya s pravom kaže da se ovo Ejubovićevo djelo može smatrati $i$ samostalnom gramatikom arapskoga jezika. ${ }^{32}$

Dakle, na osnovu ova dva kraća pregleda dviju gramatika istog autora, uviđamo prvenstveno autorov lični razvoj i usavršavanje na putu koji je prešao kako bi tadašnje udžbenike prilagodio svojim učenicima.

1.1.2. Ibrahim Opijač, ŠejhJujinučenik, kojijenapisao:

1.1.2.a.komentar na al-Muṭarrizījevu arapsku sintaksu al-Miṣbāh

1.1.2.b.al-Muhtașar fi al-naḥw (Repetitorij arapske sintakse)

1.1.2.c. mali filološki traktat na arapskom jeziku o salavatu napisanom na zidu blagajske tekije: Risāla fì šarh al-șalawāt allatī 'awradat 'alā tarīq al-'ilg̀̄àz, ili Hall luga zāwiyaBlagay. ${ }^{33}$

\footnotetext{
30 Vidjeti u: Muhamed Ždralović, „Prilog poznavanju Šejha Juje“, Bošnjačka književnost u književnoj kritici, str.352

${ }^{31}$ Amra Mulović, Arapska gramatička tradicija..., str.133

${ }^{32}$ Mustafa Jahić, Arapska gramatika..., str.15

${ }^{33}$ Hazim Šabanović, Književnost muslimana BiH..., 442-444
} 
Repetitorij arapske sintakse je posljednje njegovo djelo dovršeno 1730.godine.

1.1.3.Abdullah b. Ibrahim al-Mostari, Opijačev sin, napisao je komentar na ovo očevo djelo 1762. godine. ${ }^{34}$

1.1.4.Mahmud Sin Halilov -Damadnapisao je komentar na Mulla Džamijevo djelo o arapskoj sintaksi, ali je nedovršeno, govori samo o Akuzativima (al-Manșūbāt).

Prema nekim istraživačima, Damad je i napisao samo komentar na dio koji se odnosi na sintaksu akuzativa. ${ }^{35}$

1.1.5. Sulejman Grozdanić spominje i Mustafu Pruščaka, za kojeg tvrdi da je napisao šest djela iz oblasti arapske filologije, među kojima $i$ udžbenike arapskog jezika sa sasvim ,modernim“ $i$ samostalnim pristupom $u$ rasporedu materijala. ${ }^{36}$

1.1.6.'Abd al-Kamāl Ismā'̄ìl Travničanin napisao je gramatiku alNamliyya fi izhār al-qawā'idal-șarfiyya wa al-naḥwiyya. Naslovio ga je al-Namliyya jer se, iako nije bio naročito stručan u ovoj oblasti, trudio poput mrava (al-naml) da napiše to djelo. Napisao ga je 1642/43. godine. $^{37}$

\subsubsection{MustafaOrud $\check{z}^{38}$}

\subsection{Metrika Bošnjaka na arapskom jeziku}

1.2.1. Među Bošnjacima koji su se bavili arapskom metrikom Hazim Šabanović spominje

Mehmeda Bošnjaka Arudija, za kojeg kaže da se isticao u poznavanju arapske filologije, a naročito metrike, dodajući da je zato i dobio

\footnotetext{
${ }^{34}$ Hazim Šabanović, Književnost muslimana BiH..., str.443

${ }^{35}$ Hazim Šabanović, Književnost Muslimana BiH..., str.370

36 Sulejman Grozdanić, „Pisana riječ na orijentalnim jezicima i alhamijado“, Bošnjačkaknjiževnostuknjiževnojkritici, knjigaI, 253-270, str.261

${ }^{37}$ Hazim Šabanović, KnjiževnostmuslimanaBiH..., str.245

${ }^{38}$ Amra Mulović, ArapskagramatičkatradicijauBosni,ŠejhJujooregensu, str.11
} 
nadimak Arudi (Metričar). Međutim, naslovi njegovih djela iz ove oblasti, rukopisi i sadržaji nisu poznati. ${ }^{39}$

1.2.2.Mahmud Sin HalilovDamad ja napisao djelo iz oblasti metrike Šarḥ al 'Arūụī al-andalusī ili al-Risāla al-andalusiyya fì bayān al'awzā al- 'arabiyya, kao komentar na djelo al 'Arū ḍ al-andalusī' Abū 'Abd Allāha al-Anșārīja al-Andalusīya. Za ovo djelo se kaže da je pisano jasno, upotrebljavajući dobro odabrane primjere, zatim, vidljivo je dobro poznavanje materije i literarni arapski jezik komentatora. Sadrži definicije svih termina i tehničkih naziva iz metrike. Damad objašnjava ono što je autor al-Andalusī koncizno kazao, uz to dodajući primjere iz arapske poezije, te pomoću primjera objašnjava sve varijante metara koji proizilaze iz osnovnih šesnaest vrsta. ${ }^{40}$

\subsection{Stilistika Bošnjaka na arapskom jeziku}

Bošnjaci koju su dali doprinos u arapskoj stilistici su:

1.3.1. Hasan Kafija Pruščak (umro 1615.), napisao (1.3.1.a.) Prečišćavanje „,Sažetka“,Tamḥīṣ al-Talhnīs), kompendijsko prečišćavanje al-Qazwīnījevog djela Sažetak ,Ključa znanosti“ koje je - opet - kompendij al-Sakkākījevog djela „Ključ znanosti“. Pruščak je napisao i komentar na ovaj svoj kompendij, a to je(1.3.1.b.) Komentar „Prečišćavanja 'Sažetka'“ (Šarḥ Tamḥị̣ al-Talhīis), ${ }^{41}$ a o ovome ćebiti riječi nešto kasnije. Također, napisao je i

1.3.1.c - Risāla fĩ taḥqīq laf̣̣ ,,çelebi“6, filološku Raspravu o značenju riječi ,ç̧elebi“'. ${ }^{42}$

\footnotetext{
${ }^{39}$ Više u: Hazim Šabanović, Književnostmuslimana..., str.335

${ }^{40}$ Ibid., str.371-371

${ }^{41}$ Hazim Šabanović, Književnost muslimana BiH na orijentalnim jezicima, str.177179

${ }^{42}$ Hazim Šabanović, Književnost muslimana BiH..., str.177-179
} 
1.3.2. Muhamed Musić - Allamek (umro 1636.), napisao vrlo obimno djelo : Glosa uz al-Ğurğānījev „, Komentar 'Ključa znanosti'“" (Hāššya 'alā Šarh al-Šarīf al-Ğurğgāñ̄ 'alā Miftāḥ al 'ulūm). ${ }^{43}$

Hazim Šabanović navodi još i rukopis Hāššya 'ala šarh Mulla Ğāmī 'alā al-Kāfiya (Glosa na Mulla Džamijev komentar Ibn Hadžibove sintakse al-Kāfiya). ${ }^{44}$

1.3.3. Mustafa Ejubović Šejh Jujo (umro 1658. ili 1660.) napisao je dva djela iz oblasti stilistike čije naslove navodi njegov učenik i biograf Ibrahim Opijač, ali nijedno djelo nije pronađeno. Prvo djelo pripada vrsti metaglosa $i$ nosi naslov Glosa uz „Glosu (šayh al-islāma) alHarawīja uz 'Kompendij stilistike'“ (Hawāšš 'alā Hawāš̄ šayh al-islām al-Harawì 'alā al-Muhtașar fì al-ma 'ānì). Drugo djelo je Komentar „Uvodu u 'Kompendij stilistike"“ (Šarḥ 'alà Dibāğa al-Muhtașar fí alma'ānī). Posvećeno je samo uvodnom dijeluṬaftāzānījevog Kompendijastilistike. $^{45}$

Hazim Šabanović spominje da Šejh Jujin učenik, Ibrahim Opijač, navodi da je Šejh Jujo napisao i Šarh 'alā dībāğat al-Muhtașar fì al$m a ' \bar{a} n \bar{\imath}$, kao komentar na al-Muhtașar, ali ovo djelo nije još pronađeno. ${ }^{46}$

1.3.4. Mahmud Damad (umro 1688.), za kojeg se pretpostavlja da je napisao Djelo onovome stilu al-Badī'iyya, ${ }^{47} \mathrm{~s}$ tim da djelo nije pronađeno, a i autorstvo je sporno. ${ }^{48}$

1.3.5. Ahmed Sin Hasanov Bošnjak (umro 1775.) napisao je djelo Šarhal-Mufìd, ili Mufìd 'alā ,al-farìda“ , a koje je napisano kao

43 Vidjeti kod: Esad Duraković, Arapska stilistika u Bosni, Ahmed, Sin Hasanov Bošnjak o metafori, str.22-24, isto: Hazim Šabanović, KnjiževnostmuslimanaBiH..., str.131

${ }^{44}$ Hazim Šabanović, KnjiževnostmuslimanaBiH.., str.146

45 Esad Duraković, Arapska stilistika u Bosni..., str.25, a i u: Hazim Šabanović, Kknjiževnost muslimana BiH..., 178-179

46 Vidjeti u: Hazim Šabanović, KnjiževnostmuslimanaBiH..., str.401

${ }^{47}$ Vidjeti više u : Esad Duraković, Arapska stilistika u Bosni..., str.25, te u: Hazim Šabanović, KnjiževnostmuslimanaBiH..., str. 370-372

48 Esad Duraković, Arapska stilistika u Bosni, Ahmed, sin Hasanov Bošnjak o metafori, str. 25 
komentar al-Samarqandijevog djela al-Farīda fì al-'isti 'āra (Biser o metafori). ${ }^{49}$

\subsection{5.a Traktat o metafori Ahmeda, Sina Hasanovog}

Među ovim djelima izdvojit ćemo Bošnjakov Komentar Traktata o metafori, jer ga je Esad Duraković preveo na naš jezik i interpretirao, odnosno napisao metakomentar, a njegovo mišljenje je da je rad, između ostalog, zanimljiv jer je to jedini rad u bošnjačkoj baštini na orijentalnim jezicima, a koji je posvećen samo jednoj stilskoj figuri, za razliku od drugih, koji su posvećeni širim tematskim cjelinama ili stilistici uopće. ${ }^{50}$

Ono što karakterizira ovo djelo jeste metafora. Al-Samarkandi nižekrupne i dragocjenebisere, koji se odnose na istraživanje vrsta metafore, njenih dijelova i kontekst-riječi u tri ogrlice. ${ }^{51}$

Dakle, djelo je koncipirano na način da postoji ogrlica i u noj nanizani biseri, npr.

Ogrlica treća ima pet bisera: prvi, imaginarna metafora, drugi je realna metafora uz odgovarajući dodatak sadržaju, treći je fiktivno u poređenju s realnim kroz maštu, četvrti kontekst-riječ i peti je proširenje kontekstriječi metafore. ${ }^{52}$

Ahmed Sin Hasanov npr. Biser četvrti u Ogrlici drugoj ovako objašnjava: Nema nikakve sumnje (niti ima govora o tome) da (značenje njegovo) sadržai (koje se nalazi) u formi aludirajuće metafore (uvodi riječ „forma“ da bi obuhvatio sva tri stava) ne može biti (taj sadržaj) naveden kao jezički znak zasredstvo ( u poređenju koje je suština aludirajuće metafore) kao (što biva naveden) $\underline{\mathbf{u} \text { formi }}$ eksplicirane metafore (ovdje uvodi riječ „forma“ radi ravnoteže s prethodnom), već je riječ (i diskutabilno je), samo o neophodnosti njegova navođenja (navođenja onog sadržaja) u vlastitome jezičkom znaku (u jezičkome znaku za sadržaj), u osnovnom značenju. (Ovo razmimoilaženje odnosi se na različita shvatanja da li je tačno ili nije da

\footnotetext{
${ }^{49}$ Hazim Šabanović, Književnost muslimana BiH..., str.466

${ }^{50}$ Vidjeti kod: Durakovic, Arapska stilistika u Bosni..., str.27

51 Vidjeti više u: Ibid., str.43-44

${ }^{52}$ Ibid., str.37-82
} 
riječ-sadržaj mora imati preneseno značenje u metafori, a to je, zapravo, tačno, na što ukazuje riječima:... ${ }^{53}$, i Bošnjak nastavlja dalje svoj komentar. ${ }^{54}$

Već smo kazali da je Hasan Kafi Pruščak napisao tri filološka djela:

1.3.1.a. Tamḥīs al-talḩ̄is fī 'ilm al-balāga, djelo koje govori o arapskoj stilistici, poetici i retorici, komentar na al-Qazwīnijevo djelo Talhīs, a koje je sažetak al-Sakkākijevog Miftāḥal-'ulüma. ${ }^{55}$

Zatim, napisao je i komentar na svoj komentar, ${ }^{56}$ a o ovom djelu ćemo sada nešto više reći:

\subsection{1.b Prečišćenje Sažetka H. K. Pruščaka}

Za Pruščakovo djelo „,Tamhīs al-Talhīṣ “ (Prečišćenje Sažetka) Munir Mujić je napisao prijevod i komentar. Djelo izgleda ovako: nakon uvoda i govora o al-fașāhi i al-balāgi , prelazi se na prvi dio - znanost o značenjima ('ilm al-ma'ānī), a ovaj dio je podijeljen na osam poglavlja: modaliteti obavijesne predikacije i iskaza, stanja subjekta, stanja predikata, elementi ovisni o glagolu, restrikcija, al-’inšā iskazi, (a)sindetski odnos u rečenici i konciznost, opširnost i uobičajeni način izražavanja. Drugi dio je znanost o jasnom izražavanju ('ilm al-bayān), a ona ima tri cilja: poređenje, zatim metaforičko i doslovno značenje i alegoriju. Treći dio je znanost o pjesničkim ukrasima ('ilm al-badī'), a njih ima mnogo: semantičke figure: antiteza, kumulacija, zeugma, kopulacija, reverzija, simulacija, hiperbola, itd. Formalni pjesnički ukrasi su: paronomazija (svi njeni oblici), simploka, rimovana proza, rekurencija, rima, umetanje... ${ }^{57}$

${ }^{53}$ Ibid., str.70

${ }^{54}$ Prof. dr. Esad Duraković ovdje navodi da je podvučeni i boldirani tekst alSamarqandijev, Bošnjakov komentar u zagradama, dok je Durakovićev komentar u uglastim zagradama.V.str.39, fusnota

${ }^{55}$ Hazim Šabanović, KnjiževnostmuslimanaBiH..., str.178

${ }^{56}$ Ibid., str. 179

${ }^{57}$ Munir Mujić, Arapska stilistika u djelu Hasana Kafije Pruščaka,str. 25-123 
Pošto je svoj prvi komentar Prečišćenje napisao previše sažeto, tako da je samim time bio prilično nejasan, Pruščak je napisao Komentar Prečišćenja da bi prvenstveno njegovi učenici lakše razumjeli tekst. ${ }^{58}$

Iz ovog djela izdvojit ćemo jedan dio koji govori o paronomaziji: Ako se dvije riječi koje čine paronomaziju razlikuju po jednom glasu, koji se može nalaziti na početku, u sredini, ili na kraju, onda će se nazivati paronomazija nalikovanja ukoliko su ti glasovi međusobno bliski, kao u primjeru: „Oni zabranjuju [yanhawna] da se u Kur'an vjeruje, i sami se od njega udaljavaju [yan'awna](Q:6:26), te u primjeru:

Za čeone uvojke konja [hayl] vezano je dobro [hayr].

Ukoliko se ne radi o bliskim glasovima riječ je o pristižućoj paronomaziji. Takva je paronomazija u primjeru: „Teško svakom klevetniku [humazatin] hulitelju [lumazatin]“ (Q: 104: 1), i u primjeru: „Sam je on toga, doista, svjestan [šahīd] (Q:100: 7-8)“, te u primjeru: „Kada im dođe saznanje ['amr] o nečemu važnom ['amn] “" (Q: 4 :83). ${ }^{59}$

U svim ovim komentarima vidimo da su Bošnjaci za vrijeme Osmanskog carstva do u najsitnije detalje poznavali filološku građu na arapskom jeziku, iako im filologija nije bila jedina disciplina kojom su se bavili. Pisali su djela iz oblasti teologije, prava, filozofije, itd.

Također, naši savremenici arabisti su veoma vješto korespondirali sa osnovnim tekstom, komentarom, komentarom komentara, a uz to nam ponudili prijevod djela i naveli svoje zaključke i stavove.

Osim ovoh rukopisa, Hazim Šabanović navodi i:

1.4. Mehmed Muhtešem Velagić - Šabanović i njegov filološki komentar na Rumijevu Mesneviju Mužhir al-aškāl fì bayani lugat alMațawī. ${ }^{60} \mathrm{U}$ navodima Hazima Šabanovića ne stoji koja grana filologije je obrađena u djelu .

\footnotetext{
${ }^{58}$ Munir Mujić,Arapska stilistika u djelu Hasana Kafije Pruščaka, str.125-126, isto: Esad Duraković, ArapskastilistikauBosni..., str.22-23

${ }^{59}$ Munir Mujić, Arapska stilistika u djelu Hasana Kafije Pruščaka, str.117 ${ }^{60}$ Ibid., str. 673
} 


\section{Filologija na turskom jeziku}

Najviše doprinosa na turskom jeziku Bošnjaci su dali u divanskoj književnosti, i to u poeziji.

Što se tiče filologije, osim rječnika od kojih je najpoznatiji MakbuliArif, odnosno PoturŠahidija koji datira iz 1631.godine, nema podataka da su Bošnjaci pisali gramatike isključivo na turskom jeziku. Prva gramatika pisana rukom jednog Bošnjaka, Ibrahima Berbića, je dvojezična, tursko - bosanska, odnosno bosansko - turska, a čiji je naslov Bosansko-turski učitelj. ${ }^{61}$ Međutim, ona je pisana 1893.godine, dakle za vrijeme austrougarske vladavine Bosnom, a ne za vrijeme osmanske uprave.

Postoje podaci o djelima:

2.1. a. Prijevod i komentar arapske sintakse al-Käfiya Ibn al-Hadžiba (Ibn Hāğib) na turski

2.1.b. Prijevod i komentar gramatike arapskog jezika al-Šăfiya Ibn Hadžiba na turski jezik

2.1.c. Prijevod djela al-Daw' Tadžuddina Isfarainija... o arapskoj sintaksi, također na turski ${ }^{62}$

Sva tri ova djela pripadaju AhmeduSudiju Bošnjaku ${ }^{63}$.

Također, napisao je i komentar na perzijsko-turski rječnik spjevan u formi mesnevije Lugat-iŠahidi. ${ }^{64}$

Primjećujemo da je Sudi preveo ova djela sa arapskog jezika na turski, što nam govori da je dobro vladao i jednim i drugim jezikom, a to nije bio rijedak slučaj među Bošnjacima tog vremena.

61 Ekrem Čaušević, „Prve gramatike turskoga jezika u Bosni i Hercegovini“, ZbornikradovaofraAnđeluZvizdoviću(1498-1998.), Sarajevo - Fojnica, 2000., str.493 ${ }^{62} \mathrm{O}$ ovi djelima vidjeti više u: H. Šabanović, Književnost muslimana BiH..., str. 94, a i u: N. Karahalilović, M. Drkić, Ahmed Sudi Bošnjak: komentator arapskih klasika, str.24,

63 Šabanović navodi prijevod i komentar al-Šāfiyye, dok Halilović - Drkić spominju samo komentar.

${ }^{64}$ Karahalilović, Drkić, Ahmed Sudi Bošnjak: komentator perzijskih klasika, str.23 
Pored Bošnjaka, filologijom turskog jezika bavili su se i bosanski franjevci. ${ }^{65}$ Ovdje treba spomenuti da za vrijeme vladavine Osmanlija $\mathrm{u}$ Bosni nisu postojale etničke grupe u smislu u kojem one danas postoje, nego se pod pojmom Bošnjaci misli na osobe koje su porijeklom iz Bosne.

U fojničkom Samostanu Svetog Duha, fratri su, nakon što su turski naučili u inozemstvu (najčešće u Rimu i Bolonji), otvorili ,školu orijentalnih jezika" gdje se izučavao turski jezik, a što je ujedno i razlog da je u Fojnici i napisan najveći broj turskih rječnika i gramatika. ${ }^{66}$ Franjevci su gramatike pisali na latinskom, talijanskom i bosanskom jeziku, ${ }^{67}$ često latiničnim slovima, ${ }^{68} \mathrm{i}$ to iz misionarskih, političkih ili trgovačkih razloga ${ }^{69}$

Najstarija među ovim gramatikama je iz 1815., a najmlađa je Slovnica ili gramatika turskog jezika na sirbskom iz $1874 .{ }^{70}$ Jedna od tih

\footnotetext{
${ }^{65}$ Najiskrenije se zahvaljujem prof.dr. Ekremu Čauševiću koji mi je ukazao na svoja istraživanja i dao značajne sugestije o ovoj tematici.

${ }^{66}$ Vidjeti: Ekrem Čaušević, „Bosna-Hersek Fransısken Papayları Tarafından Yazılmış Olan Türkçe Gramerler ve Sözlükler”, Uluslararası Türkçenin Batılı Elçilerin Sempozyumu Bildirileri, 5-6 Kasım, İstanbul, 2012,s. 71, isto: Ekrem Čaušević, Marta Andrić, "Novootkriveni rukopisi bosanskih franjevaca na turskome jeziku", Prilozi zaorijentalnu filologiju, 2009., str. 170-171

${ }^{67}$ Ekrem Čaušević, Marta Andrić, „Novootkriveni rukopisi bosanskih franjevaca na turskom jeziku“, Prilozi zaorijentalnu filologiju, 2009., str.168

${ }^{68}$ U tekstu „Bosna-Hersek Papazları Tarafından Yazılmış Olan Türkçe Gramerler ve Sözlükler" Ekrem Čaušević navodi rukopise gramatika i rječnika vezanih za turski jezik koje je ranije katalogizirao Vančo Boškov (v. str. 73-83). U bilješkama vezanim za ove rukopise uglavnom stoji da su turske riječi pisane latinskim slovima, rjeđe da su pisane arapskim slovima. U tekstu "Novootkriveni rukopisi bosanskih franjevaca na turskome jeziku" ovom popisu dodaje još pet rukopisa koje je Čaušević pronašao u biblioteci franjevačkog samostana u Kraljevoj Sutjesci, v. str. 175-176

${ }^{69}$ Ekrem Čaušević, „Prve gramatike turskoga jezika u Bosni i Hercegovini““, Zbornik radova o fra AnđeluZvizdoviću, Sarajevo - Fojnica, 2000., str.491

${ }^{70}$ Ekrem Čaušević, Marta Andrić,“ Novootkriveni rukopisi bosanskih franjevaca na turskome jeziku“, str.
} 
gramatika je i Gramatika fra Andrije Glavadanovića. ${ }^{71}$ Gramatika iz 1815. godine pisana je na talijanskom jeziku. ${ }^{72}$

Također, treba spomenuti i gramatiku iz doba tanzimatskih reformi, Kavaid-iOsmaniye, štampanu 1851., koju je preveo Josip Dragomanović i naslovio je kao Kavaid-i Osmaniye ili Pravila otomanskoga jezika, spisaoMehmed Fuadi Ahmed Dževdet,nadopunio J.D., a ovaj prijevod je štampan 1873. kao prvi prijevod gramatike turskog jazika na neki strani jezik, ${ }^{73}$ što govori da su franjevci pratili ove reforme unutar Osmanskog carstva.

Dakle, iako nisu napisani na turskom jeziku, ti latinični rukopisi vrijedni su izvori za proučavanje fonetsko-fonoloških obilježja turskog idioma korištenog ne samo u Bosni, nego ina mnogo širem prostoru zapadnog Balkana. ${ }^{74}$

Gore je spomenuto da su Bošnjaci najviše na turskom jeziku ostvarili na polju divanske književnosti, dakle muslimanskom stanovništvu ovog podneblja turski je bio ne samo jezik komunikacije sa vlastima u Carigradu, nego i jezik koji se morao dobro poznavati da bi se udovoljilo zahtjevima forme i sadržaja divanske poezije, što je rezultiralo vrhunskim rezultatima na tom polju, dok je franjevcima bio jezik-sredstvo na polju misionarstva i sl., Stoga i ne čudi što su, pored bosanskog, pisali na latinskom ili talijanskom, kao jezicima koje su osjećali bližima vlastitom unutarnjem biću i poimanju svijeta, a tako su i muslimani Bošnjaci pisali gramatike najčešće na arapskom, jeziku Knjige i znanosti.

\footnotetext{
71 Ekrem čaušević, „Turska gramatika fra Andrije Glavadanovića (I)“, Prilozi za orijentalnu filologiju, 52-53, 2002/03, Sarajevo, 2004., str. 17-50, isto: Ekrem Čaušević, „Turska gramatika fra Andrije Glavadanovića (II)“, Prilozi za orijentalnu filologiju, 54/2004,Sarajevo, 2005., str. 15-50

72 Ekrem Čaušević, Marta Andrić, „Novootkriveni rukopisi...“, str.177

${ }^{73}$ Ekrem Čaušević, „Prve gramatike turskoga jezika u Bosni i Hercegovini“, str.496497

${ }^{74}$ Ekrem Čaušević, Marta Andrić, „Novootkriveni rukopisi...“ , str.173
} 


\section{Filologija na perzijskom jeziku}

Isključivo na perzijskom jeziku nije pisao nijedan od naših zemljaka. ${ }^{75}$

Što se tiče gramatike perzijskog jezika u XVI st., sami Iranci mnogo su se više bavili gramatičkim opisom arapskog, nego perzijskog jezika. ${ }^{76}$, tako da nemamo gramatika iz tog perioda pisanih na perzijskom. Međutim, iz opusa Ahmeda Suduja Bošnjaka, veoma značajnog komentatora klasičnih djela na arapskom i perzijskom jeziku unutar Osmanskog carstva, vidi se da se isključivo bavio istraživanjem gramatike arapskog i perzijskog jezika, pružajući jedan novi pristup njihovom podučavanju. ${ }^{77}$ Ipak, Sudi je ostao najviše poznat po svojim komentarima triju klasičnih tekstova na perzijskom jeziku - Sa'dijevih djela Đulistan $i$ Bustan, te Hafizovog Divana. ${ }^{78}$

\section{1.a.AhmedSudiBošnjak - Šarh-e Dīwāne Hāfez - Komentar na Hafizov Dīwān}

\section{1.b.Ahmed Sudi Bošnjak - Šarh-e Golestan - Komentar na Sa'adijev Đulistan}

\section{1.c.Ahmed Sudi Bošnjak - Šarh-e Būstān - Komentar na Sa'adijev Bustan}

\section{1.d.Ahmed Sudi Bošnjak - Komentar na Mesneviju Dželaludina}

Rumija,rukopis komentara još nije pronađen, ali pretpostavlja se da ga je napisao ${ }^{79}$

Ova djela nisu lingvistička u smislu da obrađuju neku gramatičku ili sintaksičku temu, međutim, Sudi u svojim komentarima veoma vješto ponire u najdublje smislove značenja pojedinih lingvističkih jedinica. Za njega je karakteristično to da je sva djela napisao na turskom. ${ }^{80}$ Međutim, pošto se on istinski bavio proučavanjem arapskog i

\footnotetext{
${ }^{75}$ Vidjeti u: Sulejman Grozdanić, „Pisana riječ na orijentalnim jezicima i alhamijado“, Bošnjačka knjiž., str.253-270

76 Namir Karahalilović, Munir Drkić, Ahmed Sudi Bošnjak: komentator perzijskih klasika, str.39

${ }^{77}$ Ibid., uvod (ii)

${ }^{78}$ Ibid., uvod (ii)

${ }^{79}$ Ibid., str.23

${ }^{80}$ Ibid., str. 23
} 
perzijskog, i pošto je ova tri prethodno navedena djela, koja su napisana na perzijskom, komentarisao tako da je objašnjavao pojedinosti izgovora i značenja određene riječi na perzijskom jeziku, zbog toga ove komentare obrazlažemo pod ovim naslovom.

U komentarima se bavio morfološkim opisima glagola u perzijskom jeziku $^{81}$, gramatičkom analizom ${ }^{82}$, stilistikom $^{83}$, itd.

Sudijevim komentarima bavili su se Namir Karahalilović i Munir Drkić, a ovdje ćemo navesti neka njihova zapažanja: Nakon što objasni pisanje/izgovor i gramatičke osobenosti riječi ili sintagme, autor daje njeno pravo značenje... Nakon što je objasnio sve riječi $i$ sintagme $u$ dijelu teksta podvrgnutom analizi, Sudi daje značenje čitavog odsječka teksta. ${ }^{84}$ Nakon toga prelazi na oštru kritiku ostalih komentara. ${ }^{85}$

Kod Ahmeda Sudija je primijetan utjecaj arapske gramatike, tako da on npr. u morfologiji perzijskogjezika veoma precizno određuje vrste riječi, ali se zadržava na trima vrstama - prema gramatičkom opisu arapskog jezika - imenicama (esm), glagolima (fe'l) i partikulama (harf). ${ }^{86}$

Iz sadržaja knjige Halilovića i Drkića „Ahmed Sudi Bošnjak: komentator perzijskih klasika" izdvojit ćemo: $N a$ primjeru riječi bāzargān (trgovac), Sudi daje precizno i iscrpno objašnjenje koje se može svrstati u domen historijske gramatike, odnosno promjene oblika $i$ značenja riječi uslijed njene upotrebe kroz vrijeme. Njegovo objašnjenje te riječi jeste sljedeće: „U osnovi je to riječ bāzāre $u$ značenju svega vezanog za mjesto trgovanja (bāzār), jer ortografsko $h$ (e) ukazuje na relaciju s osnovnom imenicom. Potom je to ortografsko $h$ dodavanjem sufiksa množine -ān prešlo u perzijski kaf (pa je nastao oblik bāzāregān - trgovci). Uslijed česte upotrebe, oblik riječi je skraćen: elif nakon za je ukinut (tj. [ā] je prešlo u [a]), a kesra na ra je također ukinuta, pa je nastao oblik bāzargān. Vremenom je, ponovo uslijed česte upotrebe, ovaj oblik poprimio značenje jednine (bāzargān

\footnotetext{
${ }^{81}$ Ibid., str.40

${ }^{82}$ Ibid., str.63

${ }^{83}$ Ibid., str. 100

${ }^{84}$ Ibid., str.36

${ }^{85}$ Ibid., str.37

${ }^{86}$ Ibid., str. 40
} 
- trgovac), dok se množina tvorila ponovnim dodavanjem sufiksa -ān na taj oblik (bāzargānān - trgovci). To je jasno iz primjera Mevlane Abdurrahmana Džamija, koji u sedmom poglavlju knjige Sibha alabrār navodi riječ bāzāre i sufiks množine -ān, što daje oblik bāzāregiyān (...) Sam šejh Sa'di u Bustanu navodi oblik bāzāregān u značenju jednine (...) Zato, promisli. “ (SG: 356-357)

Ovo iscrpno objašnjenje pokazuje Sudijev istančan osjećaj za gramatičke finese perzijskog jezika, dok navođenje konkretnih primjera iz perzijske književnosti svjedoči o njegovoj širokoj naobrazbi, ali $i$ akribičnosti u opisu gramatičkih osobenosti perzijskog jezika. I ne samo to, iz prethodnog primjera jasno se vidi da je Ahmed Sudi izvanredno percipirao promjene u oblicima perzijskih riječi, sve to potkrepljujući konkretnim primjerima iz književnih tekstova. Teško da bi se i danas moglo ponuditi bolje objašnjenje od Sudijevog. ${ }^{87}$

Ahmed Sudi je bio i dobar poznavalac metrike i stilistike. Tako o metru basit Sudi piše da se on nalazi samo u arapskoj književnosti, ali ne i u perzijskoj. ${ }^{88}$

\section{Zaključak}

Čitajući tekstove napisane u prošlom stoljeću (negdje do 1995. godine) o djelima napisanim na orijentalnim jezicima, često se može pročitati kako ovaj ,period nije dovoljno istražen“. Izgleda kao da je cijela jedna epoha našeg stvaralaštva zanemarena. Najviše djela pisanih u periodu između 16. i 19. st. ostajalo je ,sakriveno“ u rukopisima biblioteka po svijetu, jer su orijentalni jezici odlaskom Osmanlija postali nepoznati široj čitalačkoj publici.

Međutim, nakon 1995. godine pojavio se određeni broj prijevoda tih djela, Komentara Komentara ili Komentara Komentarovih Komentara na našem jeziku, čime je današnjem čitaocu postao dostupan još jedan dio naše književne historije. Ono što su svi naši savremenici istraživači osmanlijskog perioda u BiH zaključili, i šta su svojim prijevodima učinili dostupnim javnosti, o piscima osmanskog perioda jeste to da su ovi potonji bili izuzetni poznavaoci oblasti kojom su se bavili. Neki od njih su bili i poliscijentisti i poliglote, što svakako nije

\footnotetext{
${ }^{87}$ Ibid., str.40

${ }^{88}$ Ibid., str.44
} 
za zanemariti, pogotovo ako imamo na umu da je Bosna bila provincija unutar granica ogromnog Osmanskog carstva.

U ovom radu su navedeni samo određeni primjeri preuzeti iz istraživačkih radova bošnjačkih arabista 20. i 21. st. s ciljem da se čitaocu približi umijeće Bošnjaka koji su živjeli u vrijeme kada su Osmanlije vladale ovim prostorima, njihovo sistematizirano prilaženje tematici koja je bila aktuelna u ono vrijeme, detaljna obrada značenja određenih pojmova, komunikacija sa drugim rukopisnim djelima direktno ili indirektno, prihvatanje ili odbacivanje mišljenja drugih filologa, itd., a sve u tadašnje ,savremene“ edukacijske svrhe.

\section{Index imena i djela Bošnjaka koji su se bavili filologijom arapskog jezika:}

Gramatika i sintaksa

\subsubsection{Mustafa Ejubović Šejh Jujo :}

a. Šarh al- 'Awāmil al-m'ia (Komentar Stotinu regensa)

b. al-Fawā'id al- 'abdiyya (Savjeti Abdullahu) ili al-Unmū $\underline{d a g ̆}$

\subsubsection{Ibrahim Opijač:}

a. Šarh al-Mișbāḥ al-Muțarrizi fi al-Naḥw (Komentar Mutarrizijeve arapske sintakse al-Miṣbāḥ)

b. al-Muhtașar fi al-naḥw (Repetitorij arapske sintakse)

c. filološki traktat na arapskom jeziku o salavatu napisanom na zidu blagajske tekije: Risāla fì šarh al-șalawāt allatī 'awradat 'alā tarīq al-'ilg̀̄āz

\subsubsection{Opijačev Sin Abdullah}

1.1.4. Mahmud Sin Halilov Damad - Komentar na Mulla Džamijevo djelo o arapskoj sintaksi al-Manșūbāt - Akuzativi

\subsubsection{Mustafa Pruščak}

1.1.6. Abdulkemal Ismail Travničanin: gramatika al-Namliyya fi iẓhār al-qawā'id al-ṣarfiyya waal-naḥwiyya

\subsubsection{MustafaOrudž}

\section{Metrika}

\subsubsection{Mehmed Bošnjak Aruzi/ Arudi}




\subsubsection{Mahmud Sin Halilov - Damad (umro u Alepu 1688.):}

1. Šarh al- 'Arūẹ al-Andalusī (Komentar na djelo 'Arūḍ alAndalusī) ili al-Risāla al-andalusiyya fì bayān al-awzān al- 'arabiyya o arapskoj metrici, a koje je napisao Abū 'Abd Allāh al-Anșārī al-Analusī,

2. al-Badī 'iyya - iz oblasti stilistike, djelo nije pronađeno

Stilistika

\subsubsection{Hasan Kafija Pruščak (umro 1615.), napisao}

a. Tamhīṣ al-Talhīs (Prečišćavanje „Sažetka“), kompendijsko prečišćavanje al-Qazwīnījevog djela sažetak „Ključa znanosti“‘ koje je - opet - kompendij al-Sakkākījevog djela „Ključ znanosti““.

b. komentar na ovaj svoj kompendij, a to je Šarh Taḥmīs alTalḩiss ( Komentar „Prečišćavanja 'Sažetka'“، )

c. Risāla fi taḥīqi lafẓi „,çelebi“ “

\subsubsection{Muhamed Musić - Allamek (umro 1636.) :}

1. Hāššiya 'alā Šarh al-Šarîf al-Ğurğānī 'alā Miftāḥ al 'ulūm ( Glosa uz al-Ğurğānījev ,, Komentar 'Ključa znanosti'“")

2. Hā̄šiya 'alā šarḥ Mullā Ğāmī 'alā al-Kāfiya (Glosa na Mulla Džamijev komentar Ibn Hadžibove sintakse al-Kāfiya

1.3.3.Mustafa Ejubović Šejh Jujo (umro 1658. ili 1660.)

a. metaglosa, nosi naslov Glosa uz „Glosu (šayh al-islāma) alHarawīja uz 'Kompendij stilistike"“, Hawā̌š 'alā Hawāš̄ šayh alislām al-Harawī 'alā al-Muhtaṣar fĩ al-ma'ān̄̄

b. Komentar „Uvodu u 'Kompendij stilistike'“ Šarh 'alā Dibāğa al-Muhtașar fĩ al-ma'ān̄̄, posvećeno je samo uvodnom dijelu Ṭaftāzānījevog Kompendija stilistike

Pored ova dva, Šejh Jujin učenik, Opijač, navodi i

c. Šarḥ 'alā dībāğat al-Muhtașar fĩ al-ma‘ānī kao Šejh Jujin komentar na al-Muhtașar, ali da ovo djelo nije još pronađeno.

\subsubsection{Mahmud Damad}


1.3.5. Ahmed Sin Hasanov Bošnjak (umro 1775.) - Mufid 'alā ,alfarīda " , komentar al-Samarqandijevog djela al-Farìda fì al-'isti 'àra (Biser o metafori)

\subsubsection{Ahmed Sudi (umro nakon 1598.)}

\subsection{Mehmed Muhtešem Velagić - Šabanović}

\section{Literatura:}

1. Bošnjačka književnost u književnoj kritici, Knjiga 1, Starija književnost, prir. Enes Duraković, Esad Duraković, Fehim Nametak, Alef, Sarajevo, 1998.

2. Čaušević, Ekrem, „Prve gramatike turskoga jezika u Bosni i Hercegovini“, ZbornikradovaofraAnđeluZvizdoviću(1498-1998.), Sarajevo - Fojnica, 2000., 487-499

3. Čaušević, Ekrem, „Turska gramatika fra Andrije Glavadanovića (I)“, Prilozizaorijentalnufilologiju, 52-53, 2002/03, Sarajevo, 2004., 17-50

4. Čaušević Ekrem, „Turska gramatika fra Andrije Glavadanovića (II)“, Prilozizaorijentalnufilologiju, 54/2004, Sarajevo, 2005., str. 15-50

5. Čaušević, Ekrem, Andrić, Marta, ,Novootkriveni rukopisi bosanskih franjevaca na turskome jeziku“, Prilozizaorijentalnufilologiju, 2009., str. $167-178$

6. Čaušević, Ekrem, „Bosna-Hersek Fransisken Papazları Tarafından Yazılmış Olan Türkçe Gramerler ve Sözlükler“", UluslararasıTürkçeninBatılıElçileriSempozyumuBildirileri, 5-6 Kasım 2012, İstanbul

7. Duraković, Esad, Arapska stilistika u Bosni, Ahmed Sin Hasanov Bošnjak o metafori, Orijentalni institut, Sarajevo, 2000.

8. Karahalilović, Namir, Drkić, Munir, Ahmed Sudi Bošnjak: komentator perzijskih klasika, elektronsko izdanje, Filozofski fakultet, Sarajevo, 2014.

9. Jahić, Mustafa, Arapska gramatika u djelu al-Fawā'id al- 'abdiyya Mustafe Ejubovića, Sarajevo, 2007.

10. Mujić, Munir, Arapska stilistika u djelu Hasana Kafije Pruščaka, Orijentalni institut, Sarajevo, 2007.

11. Mulović, Amra, Arapska gramatička tradicija u Bosni: Šejh Jujo o regensu, Dobra knjiga, Sarajevo, 2012.

12. Šabanović, Hazim, Književnost Muslimana BiH na orijentalnim jezicima, Svjetlost, Sarajevo, 1973. 


\author{
Mersiha Causevic, B.A. \\ University of Bihac \\ Islamic Pedagogical Faculty \\ mersihacausevic78@yahoo.com
}

Original scientific article

\title{
PHILOLOGY OF BOSNIAKS IN ORIENTAL LANGUAGES DURING THE OTTOMAN RULE IN BOSNIA
}

\section{Abstract}

This work contains a list of philological works written by Bosniaks in the period between the 16th and 19th century, during the Ottoman rule in the territory of Bosnia. The manuscripts of these works in Arabic, Turkish and Persian language are found in libraries around the world, and the works known to us so far have been listed in the work, but there is always the possibility of finding a new manuscript (or a existing translation). Most of our philological heritage belongs to the Arabic language. Certain parts are presented from the manuscripts which have been translated into the modern Bosnian language, and from which we can see the way they were written, which classical books were the most popular, and as such served as textbooks.

One of these books is Ibn Hagib's Arabic syntaxal-Käfiyya, often commented and adapted to the needs of the then present educational system. The philological works of Hasan Kafi Pruscak are mentionedamong others, who is not known as a philologist in our country.

His interest in philology is confirmed by the fact that he corrected his comment of 'Talhis' by writing a new comment, also for educational purposes.

Also, although written in European languages, grammars of the Turkish language gained their place in this paper because the reasons why the Bosnian Franciscans wrote grammar and dictionaries are not the same as the reasons why the Muslim population learned the Turkish language. And at the end, a part of the philological discussions on the Persian language by Ahmad Sudi Bosnavi was presented.

Keywords:philology, Arabic language, Turkish language, Persian language, manuscript, grammar, sintax, commentary, Bosniak, Mustafa Ejubovic Sejh Jujo, Hasan Kafi Pruscak, Ahmed Son of Hasan, Ahmad Sudi Bosnavi, Franciscans 


$$
\begin{aligned}
& \text { المعيدة مرسيهة تشاؤشفيتش } \\
& \text { جامعة بيهاتش } \\
& \text { كلية التربية الإسلامية }
\end{aligned}
$$

mersihacausevic78@yahoo.com

علم اللغة لدى البوشناق باللغات الشرقية خلال فترة الحكم العثماني للبوسنة

\section{الخلاصة}

هذا البحث يحتوي على قائمة الأعمال في مجال علم اللغة التي كتبها البوشناق في الفترة ما بين القرنين السادس عشر والتاسع عشر خلال فترة الحكم العثماني للبوسنة.

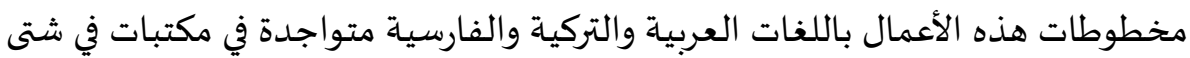

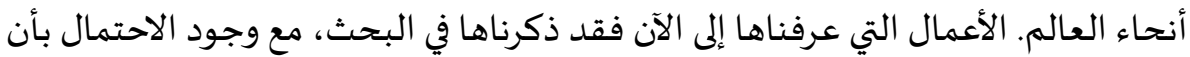
يتم الحصول على مخطوطة جديدة أو تترجم المخطوطة الموجودة.

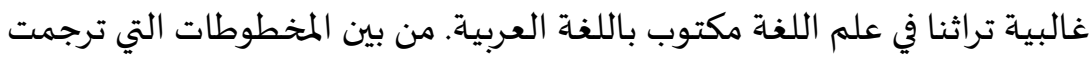

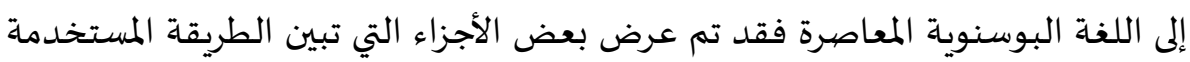
للكتابة في تلك الفترة وما هي أشهر الكتب الكلاسيكية التي كانت تستخدم للتوند التدريس.

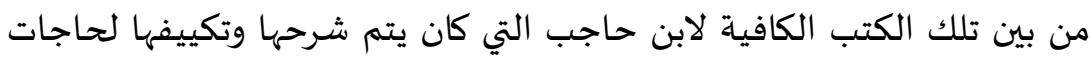
النظام التعليمي آنذاك. ومن بين تلك الكتب كتب لحسن كافي بروشتشاك (الأقحصاري) في علم اللغة، مع العلم أنه ليس مشههرًا عندنا بأنه لغوي. من بين الأدلة أنه كان لـه اله اهتمام

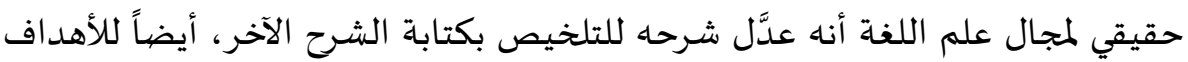
التعليمية.

كذلك كتب في مجال نحو اللغة التركية، وإن تمت كتابتها أسوة باللغات الأوروبية،

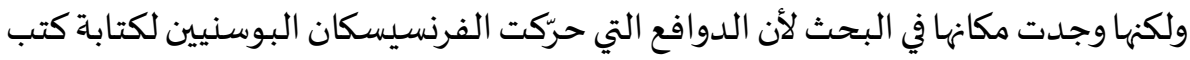

النحو والمعاجم ليست الدوافع نفسها التي دفعت السكان المسلمين لتعلم اللغة التركية. وفي الأخير تم عرض جزء من المناقشات في مجال علم اللغة حول اللغة الفارسية 
الكلمات الرئيسة: علم اللغة، اللغة العربية، اللغة التركية، اللغة الفارسية،

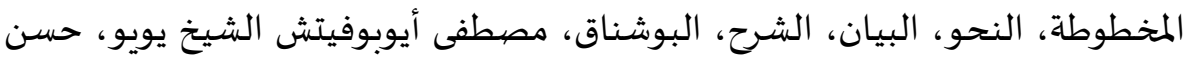

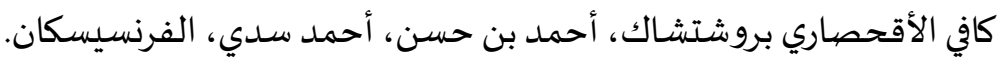

